\title{
Article \\ Neurodidactics of Languages: Neuromyths in Multilingual Learners
}

\author{
Antonia Navarro Rincón ${ }^{1, *}$, María José Carrillo López ${ }^{2}$, César Augusto Solano Galvis ${ }^{3}$ and Laura Isla Navarro ${ }^{4}$ \\ 1 Department of Language and Literature Didactics, Faculty of Education and Sport of Melilla, \\ University of Granada, Carretera Alfonso XIII, 52005 Melilla, Spain \\ 2 Department of Languages, Arts and the Sport, Faculty of Education, University of Malaga, \\ Bulevar Luis Pasteur, 29010 Malaga, Spain; mjcarrillo@uma.es \\ 3 Department of Experimental Psychology, Faculty of Education and Sport of Melilla, University of Granada, \\ Carretera Alfonso XIII, 52005 Melilla, Spain; casolano@ugr.es \\ 4 MSc Computational Linguistics with Computer Science, Center for Information and Language \\ Processing (CIS), Ludwig Maximilian University, 80539 Munich, Germany; 1.isla@campus.lmu.de \\ * Correspondence: anavarro@ugr.es
}

check for updates

Citation: Navarro Rincón, A.; Carrillo López, M.J.; Solano Galvis, C.A.; Isla Navarro, L. Neurodidactics of Languages: Neuromyths in Multilingual Learners. Mathematics 2022, 10, 196. https://doi.org/ $10.3390 /$ math10020196

Academic Editor: Jay Jahangiri

Received: 4 December 2021

Accepted: 4 January 2022

Published: 9 January 2022

Publisher's Note: MDPI stays neutral with regard to jurisdictional claims in published maps and institutional affiliations.

Copyright: (C) 2022 by the authors. Licensee MDPI, Basel, Switzerland. This article is an open access article distributed under the terms and conditions of the Creative Commons Attribution (CC BY) license (https:// creativecommons.org/licenses/by/ $4.0 /)$.

\begin{abstract}
From the perspective of neuroscience applied to education and the teaching of foreign languages, this exploratory study analyzes the beliefs and conceptions about the functioning of the brain and language learning in students enrolled in Education degrees at the Melilla campus of the University of Granada. The sample consisted of 397 participants. The data collection was carried out by means of a questionnaire designed for this purpose, consisting of questions related to the context and linguistic background of the respondents and to educational neuromyths regarding language learning. The data were analyzed using the SPSS version 27 statistical software, and univariate and bivariate analyses were carried out according to the three grouping dimensions: (a) brain functioning, (b) multiple intelligences and learning styles, and (c) language learning. The results indicate the prevalence of neuromyths related to general concepts, which determine the learning comprehension. This corroborates the findings of research studies in other contexts. Although the participants do not show a prevalence of neuromyths regarding foreign language learning, presumably due to their experiences in multilingual contexts, which constitutes the main contribution of this study.
\end{abstract}

Keywords: neurodidactics of languages; multilingualism; neuromyths; foreign language teaching and learning; second foreign language

\section{Introduction}

Since the decade of the 1990s, called the decade of the brain [1], the prefix "neuro" can be found in a number of disciplines that have been enriched by neuroscience, such as neurodidactics, neurolinguistics, and neuroeducation. This, which could well be called the "neurosemantics" of the 21st century, has spread without being accompanied by a complete explanation of learning and memory at the cellular level in the context of educational neuroscience [2]. The above does not mean that teachers who want to engage in neuroeducation must know all the secrets of neuroscience. However, they must have knowledge of what is truly relevant, such as the synaptic plasticity of the human brain, which is present throughout the life cycle [3]. Similarly, it is necessary to acquire knowledge about complex mental activities or "executive functions" and the emotional factors involved in them. Along with this, it is considered important for teachers to have knowledge of how sleep, stress, nutrition, and physical exercise influence the homeostatic functioning of the brain [4].

There are many resources on neuroeducation available, especially on the Internet. However, by reviewing such information and contrasting it with scientific publications, we found that myths continue to survive without any scientific basis and that it is quite 
common to find structured educational programs based on them. Despite the breadth and depth of research in educational neuroscience, teachers often have limited access to reputable sources, which can give rise to so-called neuromyths, such as only a small percentage of the brain is used, that there is left and right brain thinking, or that multiple intelligences exist. These types of myths fall quickly when scientific knowledge is used, since it is known that, due to the enormous neural interconnection, most of the brain is constantly used to perform daily tasks. Although technological advances in brain imaging techniques make it possible to explore delimited areas when processing specific information, thinking involves a coordinated interconnectivity of both sides of the brain. Similarly, it has been established that neuroimaging studies do not support theories of multiple intelligences [5-7].

The seminal article in neuroeducation was published by Fuller and Glendening [8] who were the first authors to propose the figure of the "neuroeducator" in the search for what they called "the good teacher". They suggested that the teacher's work should focus on the functions of the human brain in the different ways of learning. In 1988, Gerhard Preiss introduced the term neurodidactics to refer to the application of neuroscience knowledge to school teaching [9] (p. 157).

In 1997, Bruer [10] published one of the most important articles in the history of neuroeducation. In it he stated that both neuroscience and education are based on three important findings of developmental neurobiology: First, in infancy there is an increase in the number of synapses (synaptogenesis). Second, there are critical periods that depend on sensory and motor experience. Third, experiments in rats show that complex environments stimulate the formation of new synapses. It is now known that both in the olfactory bulb and in the hippocampus neural regeneration occurs at any age [11-13].

Years later, Howard-Jones et al. [14] stated that studying how the brain works can contribute, along with behavioral data, to an understanding of the underlying learning processes that will enable educators to improve teaching and learning. Educational neuroscience is not just a way to improve, explain, or analyze teaching, but it also encompasses a much broader picture: it seeks to explain how students learn and how learning changes the brain so that these findings can be applied to classroom activities [14].

A breakthrough in the understanding of what is the close relationship between neuroscience and education is found in the work of Felier and Stabio [15], who performed a deep analysis of the knowledge published to that date and established three pillars that support the solid structure of educational neuroscience: (a) the application of neuroscience to the classroom, understood as the application of advances in knowledge about the brain in the classroom and (b) interdisciplinary collaboration. In addition to the two previous pillars, the third is a language translator. This translator is the one that will provide the neuroeducation paradigm with communication codes between concepts that have been developed by various disciplines.

For many years, language was considered to be an exclusive function of the left hemisphere of the brain. This belief arose particularly from neuropsychological data with injured patients [16]. It is now well known that this is not the case because the right hemisphere is of great importance in language, and its lesion can lead to language problems $[17,18]$. This has been demonstrated in other studies in which there is evidence that bilateral lesions are necessary for more language deficits to appear, as well as evidence from functional neuroimaging studies of language tasks (such as repetition, picture naming, comprehension, and production) that are performed bilaterally [18].

Understanding the functioning of the human brain is fundamental, both in theory and in educational practice, to promote language learning and multilingualism. This inevitably involves linking cognitive neuroscience, whose functions, such as memory, language, attention, and consciousness are closely linked to affective processes, such as emotion, empathy, and motivation. 
One of the most important structures involved in learning and emotion is the hippocampus, and it is now known to be related to the ability to encode and retrieve large amounts of information. The neurobiology of this capacity has been studied for many years, and although uncertainty persists as to where and how memories are stored, the cellular mechanisms involved have been studied extensively [19]. This interest in the hippocampus is not new; however, recent publications have analyzed its function and involvement in memory from multiple areas of knowledge in order to understand the nature of learning and memory $[20,21]$. In addition, the importance of the hippocampus in emotion is due to the fact that it is part of the limbic system circuitry and is therefore involved in complex processes, such as depression [22]. All these advances in neuroscience should be used to develop didactic activities aimed at second language teaching. It is of vital importance to be able to transfer this knowledge to the classroom because otherwise a true neuroeducational practice will not be achieved.

The above is related to the third pillar, referred to by Felier and Stabio [15], because it allows the development of activities using the appropriate concepts in order to keep neuromyths out of the way. Having the flexibility to handle concepts from other scientific disciplines decreases the risk of myths intermingling in classroom activities, myths that still persist today among education professionals [23].

\section{Objectives and Research Foundation}

The challenge today is to apply all the neuroscientific knowledge that has been produced in the last twenty years to teaching, particularly to second language teaching. To do so, it is necessary to establish points of convergence around the fundamentals of neuroeducation in relation to foreign language teaching. In this sense, the neurodidactics of languages [24,25] seeks to confront the discoveries of neurophysiology, educational techniques, and the types of learning and teaching of foreign and second languages. It aims to know the real impact of foreign language teaching methodologies on brain functions and to determine the teaching and learning activities that allow optimal exploitation of all mental faculties. A pioneering proposal, framed in the field of neurosciences and neuroeducation, is the Neurolinguistic Approach to the teaching of French as a second and foreign language [26], whose authors are Claude Germain and Joan Netten. It is a transdisciplinary and sociocognitive approach, known as Intensive French, which was initially tested in Canada, and then after appropriate adaptations, in other countries including China, Taiwan, Iran, Japan, Belgium, and France. According to Germain [27], it is a new paradigm, a change in the conception of the relationship between appropriation (understood as nonconscious acquisition or conscious learning) and second and foreign language teaching, with the aim of creating in the classroom the optimal conditions for spontaneous communication and successful interaction in a second (L2) or foreign language (FL). The preferred strategies come from neuroscience research [28]. The theoretical foundations of the Neurolinguistic Approach are Cummins' hypothesis of interdependence between languages [29], Damasio y Damasio [30], the "iceberg theory" by Cummins and Swain [31], Vigotsky's theory [32], Paradis' neurolinguistic theory of bilingualism [33-35], and Transfer Appropriate Processing in Ellis [36] and Segalowitz [37].

Some of the most common myths or beliefs about the brain and second language learning, according to Paredes [38] (pp. 191-192), are: (a) Those who are proficient in a foreign or second language have an easier time learning other languages. (b) A foreign language is easier to learn when it is closer to the mother tongue from the point of view of its genealogy. (c) There is a critical period for language learning. According to data obtained from questionnaires on neuromyths in different countries [39] (p. 15) [40,41], there is a prevalence of those referring to learning style, in the sense of erroneously stating that students learn better when they receive information in their preferred learning style [5,42-47], hemispheric dominance as an explanation for differences among learners [42,47], and neuromyths about coordination exercises, sugar intake, and the use of only $10 \%$ of the brain. 
It is now known that there are qualitative differences in how native and non-native speakers process linguistic information. In this sense, it has been established that, unlike the critical or sensitive period approach, it is the type of experience that shapes the conceptual building blocks of the second language [48]. Hence the importance of exploring aspects of the learner's linguistic context, such as those pointed out by Couëtoux-Jungman et al. [49] (p. 299) on language contact in the environment since childhood, the language spoken by parents, relatives, and close friends; and the motivation towards language choice. It should also be noted that multilingualism does not necessarily involve understanding that one must master several languages at the same level. A multilingual is someone who has, compared to his or her mother tongue, more or less reduced knowledge (or partial competence, according to the Common European Framework of Reference for Languages (CEFR) [50,51] of two or more languages in the same or different registers of competence (e.g., to ensure oral or written contacts for reading and to carry out professional interactions) [52].

Breakthroughs in neuroscience have provided evidence that linguistic aspects, which only partially overlap between the mother tongue (L1) and the second language (L2), tend to generate different neurophysiological responses. The findings indicate that the level of practice difficulty can be manipulated to engage specific neurological pathways, even when practical performance appears similar on the surface, individual brain responses predict learning success rates as measured on written tests [53]. These data provide direct evidence that teaching material can be modified as appropriate in order to achieve a given brain activation.

This neuroscience research about certain structures in charge of complex processes, both executive and emotional functions, should feed any neuroeducational program for language learning, hence the importance of considering the prior knowledge and beliefs that students enrolled in Education degrees have about this field. The objectives of the present study are:

1. Describing the linguistic profile of the university students participating in this study, who are enrolled in degrees in Education at the Melilla campus.

2. Exploring their beliefs of neuromyths related to the functioning of the brain, multiple intelligences and learning styles, and language learning.

The following questions will be addressed:

1. What is the linguistic profile of the students enrolled in degrees in Education at the Melilla campus?

2. What beliefs do the respondents have regarding education neuromyths and language learning?

3. Are there significant differences in the responses given a series of descriptive variables and dimensions?

\section{Materials and Methods}

In order to achieve the proposed objectives, an exploratory analysis was carried out. A quantitative approach was used to evaluate the prevalence of neuromyths in the educational environment of the subjects participating in the study.

\subsection{Participants}

The research was restricted to university students enrolled in the degrees in Early Childhood Education and Primary Education, and in the double degrees in Primary Education and Physical Activity and Sport and Social Education of the Faculty of Education and Sport of Melilla. The population is made up of the students enrolled $(N=818)$ during the academic year 2020-2021.

The final sample size was 397, which constitutes an error rate of $3.5 \%$, below the commonly accepted and assumed error rate of $5 \%$, which is commonly accepted and assumed in the educational field (5\%) and would result in a sample size of 262. 
The selection of participants, however, was not random but by convenience, which is perceived as a limitation. The sample was made up of $24.2 \%$ of students in the Primary Education Degree, 20.7\% in Early Childhood Education, 22.9\% in Social Education, and $32.2 \%$ in the double degree. A total of $76.8 \%$ of the students reside in Melilla, and $23.2 \%$ come from other regions of Spain. We observed that $95 \%$ are of Spanish nationality, 4\% Moroccan, $0.8 \%$ French, and $0.3 \%$ Swiss. Those who said that they were in contact with at least two languages during their childhood represent $52.6 \%$ of the total. A total of $47.9 \%$ has only one mother tongue (Spanish), and $52.3 \%$ said they have a second mother tongue. The combinations of mother tongues in the same subject are: Spanish and Tamazight (39.5\%); Spanish and French (4.8\%), and, finally, Spanish and Arabic (8\%). The rate of feminization is very high $(81.9 \%)$ compared to that of men $(18.1 \%)$.

\subsection{Ethical Considerations}

The ethical guidelines for this type of research were followed, guaranteeing the voluntariness and anonymity of the participants in the study, as well as the processing of data exclusively for statistical purposes derived from the research.

\subsection{Instruments}

A two-part questionnaire was developed (Appendix A). The first part asked for personal and academic data related to language learning and ability, and the second part offered 12 items presented in the form of statements, with respondents having to answer by choosing one of three options (Agree, Disagree or Don't know). Following the aims of the present study, the items were selected and adapted from existing questionnaires (Appendix B), such as the BALLI instrument, The Beliefs About Language Learning Inventory [54], the Neuroscientific Literacy Study [55], and others that have been evaluated in various countries [39] (p. 15) [40,41].

The questionnaire initially contained 13 items and was submitted to experts for judgment, whose task was to assess the clarity of the items, the appropriate language, the interpretation of the content, and the degree of representativeness referred to the assessment of each of the statements regarding educational neuromyths and language learning.

The validation of the content based on concordance analysis, derived from the experts' assessments, was stark. All experts accepted the instrument and highlighted its drafting, relevance, and opportunity. It was then unnecessary to use Kendall's concordance statistic, which was going to be employed [56].

After validating the content, the assessment or analysis of the global reliability of the instrument was carried out. To this end, Cronbach's alpha was computed, obtaining an excellent value $(\alpha=0.084)$, after eliminating an item that reduced the value to a barely acceptable $(\alpha=0.695)$, hence the decision to discard it, as is common in education research $[56,57]$. Once the consistence was calculated and to complete the validity in this occasion, the instrument underwent the Factorial Exploratory Analysis (FEA), and the Confirmatory (FCA), as appropriate in the instrumental validation $[57,58]$, grouped the items in 3 factors or dimensions: 1 . functioning of the brain, 2. beliefs in multiple intelligences and learning styles, and 3. language learning. The partial consistency of each factor resulted in high and excellent values $\left(\alpha_{\text {factor } 1}=0.896 ; \alpha_{\text {factor } 2}=0.915\right.$; and $\left.\alpha_{\text {factor3 }}=0.860\right)$, according to the conceived values in the education field [56,57].

Next, the followed procedure is detailed for the latter, and Table 1 shows the items and corresponding dimensions. A pretest was given to 200 students. After review and analysis of the results by the experts, the item Students who are successful in mathematics or science are not usually good at learning languages was eliminated due to the almost unanimous response $(92.2 \%)$ of the participants, who disagreed with this statement. Therefore, the second part of the final questionnaire consisted of 12 items to ensure the participation and interest of the respondents. No explicit reference was made to the term 'neuromyth' either in the title or in any of the sections of the questionnaire so as not to influence the answers given. 
The selected statements explore the learners' beliefs and implicitly contain predominant neuromyths identified in the field of language learning.

Table 1. Items of the final questionnaire and dimensions for data collection.

\begin{tabular}{|c|c|c|}
\hline Items & Dimensions & Cronbach's Alpha \\
\hline $\begin{array}{l}\text { 1. It is no longer possible to learn a foreign language } \\
\text { (FL) well beyond a certain age. }\end{array}$ & Dimension 3 & $\alpha=0.806$ \\
\hline $\begin{array}{l}\text { 2. The ease of learning languages depends on a } \\
\text { specific type of intelligence. }\end{array}$ & Dimension 2 & $\alpha=0.915$ \\
\hline $\begin{array}{l}\text { 3. People preferably use one of the two hemispheres } \\
\text { (either the right or the left) to learn languages. }\end{array}$ & Dimension 1 & $\alpha=0.896$ \\
\hline $\begin{array}{l}\text { 4. You only really learn a FL when you interact in } \\
\text { real situations. }\end{array}$ & Dimension 3 & $\alpha=0.806$ \\
\hline $\begin{array}{l}\text { 5. It is more difficult for a person who speaks a FL to } \\
\text { learn others. }\end{array}$ & Dimension 3 & $\alpha=0.806$ \\
\hline $\begin{array}{l}\text { 6. When the learner is taught in the preferred sensory } \\
\text { modality (visual, auditory, kinaesthetic) better } \\
\text { academic performance is obtained. }\end{array}$ & Dimension 2 & $\alpha=0.915$ \\
\hline $\begin{array}{l}\text { 7. Sufficient grammar and vocabulary must be learned } \\
\text { before beginning to express oneself in a FL. }\end{array}$ & Dimension 3 & $\alpha=0.806$ \\
\hline 8. We only use $10 \%$ of our brain. & Dimension 1 & $\alpha=0.896$ \\
\hline 9. Multiple intelligences contribute to learning FL. & Dimension 2 & $\alpha=0.915$ \\
\hline $\begin{array}{l}\text { 10. I have a very good memory just for retaining } \\
\text { foreign language words. }\end{array}$ & Dimension 1 & $\alpha=0.896$ \\
\hline $\begin{array}{l}\text { 11. Children should learn their native language before } \\
\text { they start learning a FL otherwise, they will not fully } \\
\text { learn either one. }\end{array}$ & Dimension 3 & $\alpha=0.806$ \\
\hline $\begin{array}{l}\text { 12. Learning style determines how languages are } \\
\text { acquired. }\end{array}$ & Dimension 2 & $\alpha=0.915$ \\
\hline & TOTAL & $\alpha=0.884$ \\
\hline
\end{tabular}

\subsection{Data Collection Procedure}

Students were invited to participate voluntarily and anonymously in this study by completing the questionnaire via the web using the Google Form application. The passing of the questionnaire took place between September 2020 and January 2021.

\subsection{Data Analysis}

Having established the factors of the questionnaire and Cronbach's alpha to determine its reliability, we proceeded to the frequency and percentage analysis, as a measure of the distribution of the participants' responses, contemplating the following descriptive variables: gender, place of residence, one mother tongue or more than one, degree, course, languages in contact during childhood, languages in which parents and relatives speak to you, accreditation of language proficiency, CEFR level certification [32]. This was followed by Levene's test, which found that the data obtained did not follow homogeneity of variances; i.e., it lacked homoscedasticity. Accordingly, nonparametric tests, such as the Mann-Whitney U and Kruskal-Wallis K tests, were used. Both data were calculated using the IBM SPSS version 27 statistical software, and in all calculations a significance level ( $p$-value) of 0.05 or $5 \%$ error was assumed.

\section{Results}

After distributing the participants' responses (Table 2), to proceed with the exploratory analysis of the results in each of the dimensions, two types of descriptive analyses were carried out, which provided relevant information on the characteristics of the sample. The first, univariate, to study the frequency distribution and the other, bivariate, to detect possible differences between the items and the descriptive variables. 
The frequency distribution and percentages of the participants, the descriptive variables (Table 2) confirm that, regarding gender, the female rate is very high $(81.9 \%)$, in comparison to that of the male gender $(18.1 \%)$. The respondents who live in Melilla represent the $76.8 \%$, while the other $23.2 \%$ comes from other regions in Spain. In relation to their certifications and degrees (Table 2), 24.2\% are students enrolled in the Primary Education degree, 20.7\% in Early Childhood Education, 22.9\% in Social Education, and $32.2 \%$ in the double degree. A total of $46.9 \%$ only has one mother tongue (Spanish), and $53.1 \%$ has more than one mother tongue. Those who indicated having exposure to at least two languages during their childhood represent $52.6 \%$ of the total. From this percentage, $14.9 \%$ considers their second mother tongue to be Spanish, 30.7\% Tamazight, 4.8\% Arabic, and $2.8 \%$ French. The combinations of mother tongues for the same subject are: Spanish and Tamazight (39.8\%); Spanish and Arabic (7.8\%) and, finally, Spanish and French (6.5\%). The majority (91.2\%) learned a first foreign language during their whole preuniversity education, generally English, and $43.8 \%$ also opted for French as a second foreign language. A total of $63.5 \%$ has an accreditation for their linguistic capabilities in the first foreign language, and $36.5 \%$ does not possess such certification.

Table 2. Frequency distribution and percentages of the participants according to the descriptive variables.

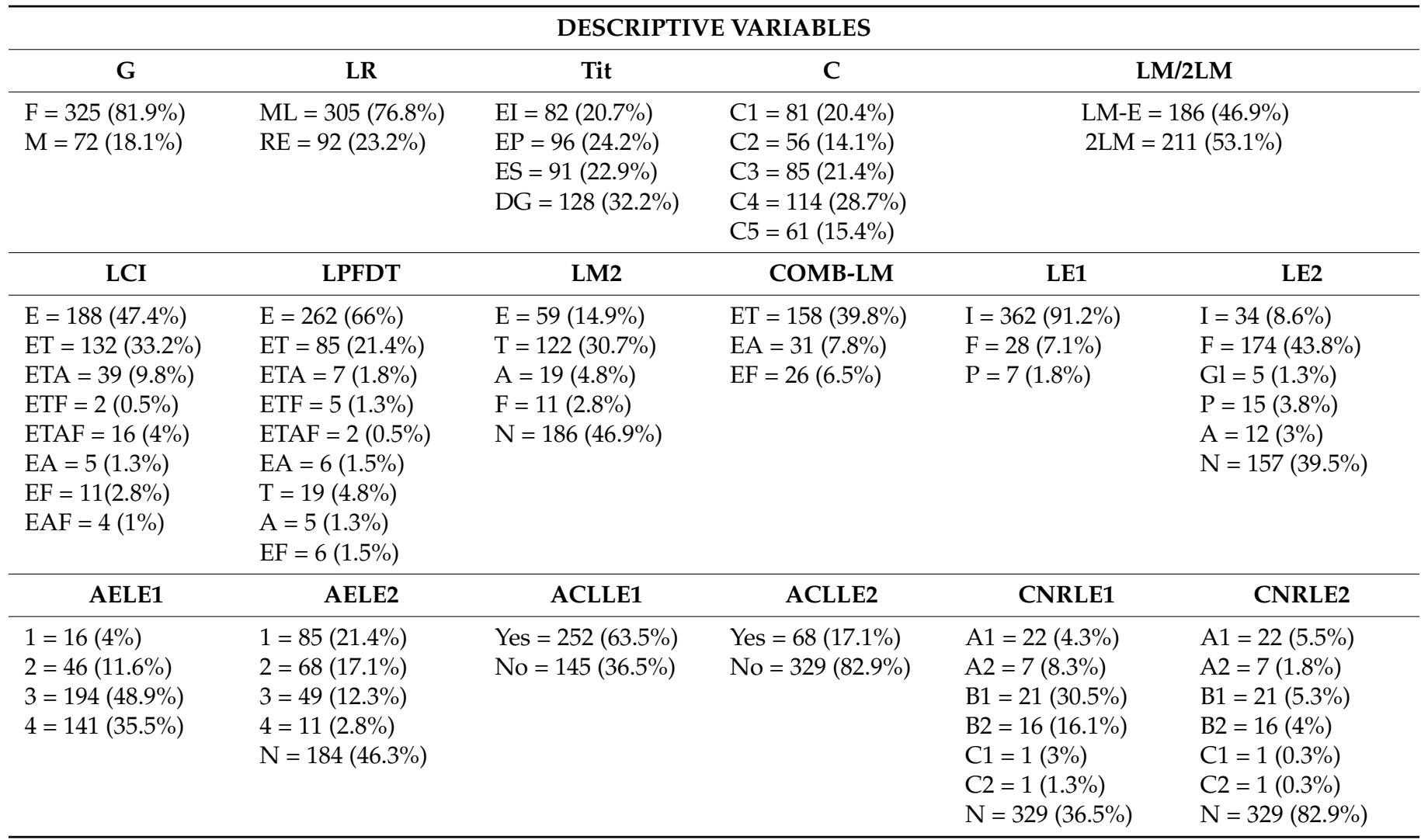

Note: $\mathrm{G}=$ Gender; $\mathrm{F}=$ Female; $\mathrm{M}=$ Male; $\mathrm{LR}=$ Place of residence; $\mathrm{ML}=$ Melilla; RE = Rest of Spain; Tit = Degree EI = Early Childhood Education; EP = Primary Education; ES = Social Education; DG = Double Degree; C = Year of study; $\mathrm{C} 1$ = First year; $\mathrm{C} 2$ = Second year; $\mathrm{C} 3=$ Third year; $\mathrm{C} 4=$ Fourth year; $\mathrm{C} 5=$ Fifth year; $\mathrm{LM}=$ One mother tongue; $2 \mathrm{LM}=$ More than one mother tongue; $\mathrm{LM}-\mathrm{E}=$ Spanish as only mother tongue; $\mathrm{LCI}=$ Languages in touch with during childhood; $\mathrm{E}=$ Spanish; $\mathrm{T}$ = Tamazight; $\mathrm{A}=$ Arabic; $\mathrm{F}=$ French; $\mathrm{I}=$ English; $\mathrm{P}=$ Portuguese; $\mathrm{Gl}=$ German; ET = Spanish and Tamazight; ETA = Spanish, Tamazight, and Arabic; ETF = Spanish, Tamazight, and French; ETAF = Spanish, Tamazight, Arabic, and French; EA = Spanish and Arabic; EF = Spanish and French; $\mathrm{LPFDT}=$ Languages in which parents and relatives speak to you; LM2 =Second mother tongue; COMB-LM = Mother tongue combinations; LE1 = First foreign language; AELE1 = Years of study of the LE1; $1=$ From 1 to 3 years; 2 = From 4 to 7 years; $3=$ From 8 to 14 years; $4=$ More than 14 years; ACLLE1 = Certification of language proficiency for the LE1; CNRLE1 = Level acquired for the LE1 certification; $\mathrm{A} 1=\mathrm{A} 1$ level; $\mathrm{A} 2$ = A2 level; $\mathrm{B} 1=\mathrm{B} 1$ level; $\mathrm{B} 2$ = $\mathrm{B} 2$ level; $\mathrm{C} 1$ = $\mathrm{C} 1$ level; $\mathrm{C} 2$ = $\mathrm{C} 2$ level; $\mathrm{N}$ = None; $\mathrm{LE} 2=$ Second foreign language; $\mathrm{AELE} 2$ =Years of study of the LE2; ACLLE2 = Certification of language proficiency for the LE2; CNRLE2 = Level acquired for the LE2 certification. 


\subsection{Dimension 1 Brain Functioning}

\subsubsection{Univariate Analysis}

Regarding item 3, which refers to the interaction of the hemispheres, just $20 \%$ responded correctly. Another relevant fact is that less than $12 \%$ answered correctly to item 8 We only use $10 \%$ of our brain, which suggests a lack of knowledge of how the human brain functions. Similarly, with regard to memory, a large majority $(60.2 \%)$ stated that they had a good memory just to retain words in the foreign language (Figure 1).

. People preferably use one of the two hemispheres (either the right or the left) to learn languages.

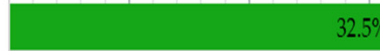

\section{$5 \%$}

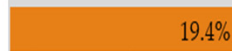

\section{$19.4 \%$} $48.1 \%$

8. We only use $10 \%$ of our brain.

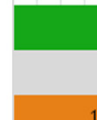

\section{$11.6 \%$}

10. Ihave a good memory just to retain words from foreign language.

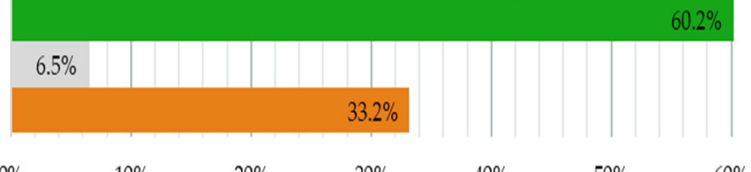

$0 \%$

$30 \%$

$40 \%$

$60 \%$

agree Don'tknow Disagree

Figure 1. Frequency distribution of the items that make up Dimension 1. Functioning of the brain.

\subsubsection{Bivariate Analysis}

In the bivariate analysis of item 3, People preferably use one of the two hemispheres (either the right or the left) to learn foreign languages (Table 3), there are significant statistical differences $(p=0.011)$ among those who believe that there is effectively a disconnection between the brain hemispheres. A slightly higher percentage of women selected the options Don't know or Agree (49.2\% and 34.2\%, respectively). For their male counterparts, these percentages are $43.1 \%$ and $25 \%$, respectively. The variable one mother tongue or more than one mother tongue also marks a difference $(p=0.000)$ among the respondents who have more than one mother tongue and those who have Spanish as their only mother tongue $(51.9 \%$ and $25.2 \%$, respectively) and selected those options. The variable Languages in which parents and relatives speak to you, the difference $(p=0.000)$ is present between the Spanish subgroup $(25.2 \%)$, on one side, and the Spanish and Tamazight subgroup $(60 \%)$, on the other, both agreeing with the item (Table 3).

According to the results obtained from the bivariate analysis on item 8 , We only use $10 \%$ of our brain (Table 3), there are significant statistical differences, confirmed by the Mann-Whitney or Kruskal-Wallis tests, among those who wrongly agree with the item regarding the following variables: gender $(p=0.000), 43.1 \%$ of the female group compared to $66.7 \%$ of the male group; place of residence $(p=0.022), 44.9 \%$ of those living in Melilla compared to $55.4 \%$ of those from other regions in Spain; year of study ( $p=0.019), 40 \%$ enrolled in third year and $56.1 \%$ in fourth year, with a difference of more than 16 points; degree $(p=0.023), 41.8 \%$ enrolled in the Social Education degree compared to $52.3 \%$ in the double degree with a difference of 10 points; Languages in contact during childhood ( $p=0.011)$, with a difference of almost 12 points between those who were exposed only to the Spanish language $(52.1 \%)$ versus those exposed to the Spanish and Tamazight languages (40.8\%); the accreditation of language proficiency $(p=0.000), 54.9 \%$ of those who have a certificate of language proficiency in their first 
foreign language according to the CEFR and the $36.6 \%$ of those who do not hold any certificate.

As for item 10, I have a very good memory just for retaining words in the $F L$, we found that $65.6 \%$ of the respondents in the degree in Primary Education, and $43.9 \%$ of those in the degree in Early Childhood Education affirmed that they memorize well only the the words in the FL, with a difference of more than 20 points between both subgroups, which is corroborated by the Kruskal-Wallis test $(p=0.003)$. There is a significant statistical difference, according to the Mann-Whitney test $(p=0.001)$, of 16 points between those who agree on the item, depending on whether they have an accreditation of language proficiency in their first foreign language $(67 \%)$ or not $(50.6 \%)$. More specifically, between those subgroups that accredit levels A2 (36.4\%) and B1 (65.3\%) of the CEFR, a difference validated by the Kruskal-Wallis test $(p=0.002)$.

Table 3. Comparative statistics for Dimension 1. Functioning of the brain.

\begin{tabular}{|c|c|c|c|c|c|c|c|c|c|}
\hline Items & $\mathrm{G}$ & LM/2LM & LR & $\mathrm{C}$ & Tit & LCI & ACLLE1 & LPFDT & CNRLE1 \\
\hline & $\begin{array}{l}\mathrm{F}=325 \\
\mathrm{M}=72\end{array}$ & $\begin{array}{l}\mathrm{LM}-\mathrm{E}= \\
186 \\
2 \mathrm{LM}=211\end{array}$ & $\begin{array}{l}M L=305 \\
R E=92\end{array}$ & $\begin{array}{l}\mathrm{C} 1=81 \\
\mathrm{C} 2=56 \\
\mathrm{C} 3=85 \\
\mathrm{C} 4=114 \\
\mathrm{C} 5=61\end{array}$ & $\begin{array}{l}\mathrm{EI}=82 \\
\mathrm{EP}=96 \\
\mathrm{ES}=91 \\
\mathrm{DG}=128\end{array}$ & $\begin{array}{l}E=188 \\
E T=132 \\
E T A=39 \\
E T F=2 \\
E T A F=16 \\
E A=5 \\
E F=11 \\
E A F=4\end{array}$ & $\begin{array}{l}\text { Yes }=253 \\
\text { No }=145\end{array}$ & $\begin{array}{l}E=262 \\
E T=85 \\
E T A=7 \\
E T F=5 \\
E T A F=2 \\
E A=6 \\
T=19 \\
A=5 \\
E F=6\end{array}$ & $\begin{array}{l}\mathrm{A} 1=17 \\
\mathrm{~A} 2=33 \\
\mathrm{~B} 1=121 \\
\mathrm{~B} 2=64 \\
\mathrm{C} 1=12 \\
\mathrm{C} 2=5 \\
\mathrm{~N}=145\end{array}$ \\
\hline 3 & $\begin{array}{l}\mathrm{U}=9626 \\
p=0.011\end{array}$ & $\begin{array}{l}\mathrm{U}=13,393 \\
p=0.000\end{array}$ & & & & & & $\begin{array}{l}\mathrm{EF}=\mathrm{b} \\
\mathrm{K}=42.399 \\
p=0.000\end{array}$ & \\
\hline 8 & $\begin{array}{l}\mathrm{U}=8701.5 \\
p=0.000\end{array}$ & & $\begin{array}{l}\mathrm{U}= \\
12,029.5 \\
p=0.022\end{array}$ & $\begin{array}{l}\mathrm{K}=5.489 \\
p=0.019\end{array}$ & $\begin{array}{l}\mathrm{K}=5.19 \\
p=0.023\end{array}$ & $\begin{array}{l}\mathrm{K}=6.401 \\
p=0.011\end{array}$ & $\begin{array}{l}\mathrm{U}= \\
15379.5 \\
p=0.000\end{array}$ & & \\
\hline 10 & & & & & $\begin{array}{l}\mathrm{K}=8.79 \\
p=0.003\end{array}$ & & $\begin{array}{l}\mathrm{U}=11.583 \\
p=0.001\end{array}$ & & $\begin{array}{l}\mathrm{K}=9.583 \\
p=0.002\end{array}$ \\
\hline
\end{tabular}

Note: $\mathrm{G}=$ Gender; $\mathrm{F}=$ Female; $\mathrm{M}=$ Male; $\mathrm{LM}=$ One mother tongue; $2 \mathrm{LM}=$ More than one mother tongue; LM-E $=$ Spanish as only mother tongue; $\mathrm{LR}=$ Place of residence; $\mathrm{ML}=$ Melilla; $\mathrm{RE}=$ Rest of Spain $\mathrm{C}=$ Year of study $\mathrm{C} 1=$ First year; $\mathrm{C} 2=$ Second year; $\mathrm{C} 3=$ Third year; $\mathrm{C} 4=$ Fourth year; $\mathrm{C} 5=$ Fifth year; Tit $=$ Degree; EI = Early Childhood Education; EP = Primary Education; ES = Social Education; DG = Double Degree; LCI = Languages in touch with during childhood; ET = Spanish and Tamazight; ETA= Spanish, Tamazight, and Arabic; ETF = Spanish, Tamazight, and French; ETAF = Spanish, Tamazight, Arabic, and French; EA = Spanish and Arabic; EF = Spanish and French; ACLLE1 = Certification of language proficiency for the LE1; LPFDT $=$ Languages in which parents and relatives speak to you; $\mathrm{T}=$ Tamazight; $\mathrm{A}=\mathrm{Arabic}$; $\mathrm{CNRLE1}=$ Level acquired for the LE1 certification; $\mathrm{A} 1=$ A1 level; $\mathrm{A} 2$ = A2 level; $\mathrm{B} 1$ = $\mathrm{B} 1$ level; $\mathrm{B} 2$ = $\mathrm{B} 2$ level; $\mathrm{C} 1$ = $\mathrm{C} 1$ level; $\mathrm{C} 2=\mathrm{C} 2$ level; $\mathrm{N}=$ None; $\mathrm{U}=$ Mann-Whitney test; $p=p$-value; $\mathrm{K}=$ Kruskal-Wallis test.

\subsection{Dimension 2 Beliefs on Multiple Intelligences and Learning Styles}

\subsubsection{Univariate Analysis}

The univariate analysis of the items that make up the second dimension shows that the participants in the study are convinced of the influence of multiple intelligences, learning styles, and sensory modality on language learning (Figure 2). Likewise, there is a clear increase in the number of Agree responses for the items 6, 9, and 12. A total of 58.44\% thinks that multiple intelligences contribute to language learning; some $79.6 \%$ considers that the use of the preferred sensory modality has an impact on better academic performance, and the vast majority $(83.63 \%)$ believes that learning styles are determinant for learning. In fact, the answers given to item 2 indicate that slightly more than a third of the participants $(34.5 \%)$ think that the ability to learn foreign languages is conditioned by some specific type of intelligence, compared to $53.7 \%$ who rightly thinks the opposite. 




Figure 2. Frequency distribution of the 4 items that make up Dimension 2. Beliefs on multiple intelligences and learning styles.

\subsubsection{Bivariate Analysis}

The analysis provides evidence of the existence of significant statistical differences (Table 4) for item 2, The ease of learning languages depends on a specific type of intelligence and the following two variables: (a) languages in contact during childhood ( $p=0.005)$, since $60.6 \%$ of the participants of the Spanish and Tamazight language subgroup and $35.9 \%$ of the Spanish, Tamazight, and Arabic subgroup both answered Disagree with the item, with a difference of almost 25 points between them; and (b) Years of second foreign language study $(p=0.011)$, the difference marked by the Kruskal-Wallis test, since $30.4 \%$ of the subgroup had been studying their second foreign language between 4 and 7 years, and $51 \%$ of the subgroup had been studying between 8 and 14 years, with a difference of more than 20 points, as shown by the results of the Kruskal-Wallis test.

Regarding item 9, Multiple intelligences contribute to the learning of foreign languages, the statistical significant differences are found in relation to the Agree option and the following variables (Table 4$)$ : (a) gender $(p=0.000)$, shown by the Mann-Whitney test, $40.3 \%$ of the male group and $62.5 \%$ of the female group; (b) one mother tongue or more than one mother tongue $(p=0.001)$, a difference evidenced by the Mann-Whitney test, half $(51.9 \%)$ of the respondents, whose only mother tongue is Spanish, as well as $71.1 \%$ of those who are bilingual, with a difference of 20 points; (c) year of study ( $p=0.001), 58.40 \%$ of the participants formed by $42.9 \%$ of the students in second year and $71.8 \%$ of those in third year; (d) certificate for their first foreign language $(p=0.000), 23.5 \%$ of those who have A1 and $72.7 \%$ of those who have A2, and ( $p=0.038), 63.6 \%$ of those with B1 and $50 \%$ of those with B2; (e) Years of study of the second foreign language ( $p=0.033$ ), $67.1 \%$ of the respondents who have been studying their second foreign language between 1 and 3 years and $49.3 \%$ of those who have been studying their FL2 between 4 and 7 years, with a difference of more than 17 points between the former and the latter; (f) Languages in which parents and relatives speak to you $(p=0.001), 51.9 \%$ of those only exposed to Spanish and $71.8 \%$ of those exposed to both the Spanish and Tamazight languages, with a difference of more than 19 points between them. 
Table 4. Comparative statistics on the beliefs on the multiple intelligences and learning styles.

\begin{tabular}{|c|c|c|c|c|c|c|c|c|c|c|}
\hline Items & $\mathrm{G}$ & LM/2LM & AELE2 & $\mathrm{C}$ & Tit & LCI & ACLLE1 & LE1 & LPFDT & CNRLE1 \\
\hline & $\begin{array}{l}F=325 \\
M=72\end{array}$ & $\begin{array}{l}\text { LM-E = } \\
186 \\
2 \mathrm{LM}=211\end{array}$ & $\begin{array}{l}1=85 \\
2=68 \\
3=49 \\
4=11 \\
N=184\end{array}$ & $\begin{array}{l}C 1=81 \\
C 2=56 \\
C 3=85 \\
C 4=114 \\
\text { C5 }=61\end{array}$ & $\begin{array}{l}\mathrm{EI}=82 \\
\mathrm{EP}=96 \\
\mathrm{ES}=91 \\
\mathrm{DG}=128\end{array}$ & $\begin{array}{l}\mathrm{E}=188 \\
\mathrm{ET}=132 \\
\mathrm{ETA}=39 \\
\mathrm{ETF}=2 \\
\mathrm{ETAF}=16 \\
\mathrm{EA}=5 \\
\mathrm{EF}=11 \\
\mathrm{EAF}=4\end{array}$ & $\begin{array}{l}\text { Yes }=252 \\
\text { No }=145\end{array}$ & $\begin{array}{l}I=362 \\
F=28 \\
P=7\end{array}$ & $\begin{array}{l}\mathrm{E}=262 \\
\mathrm{ET}=85 \\
\mathrm{ETA}=7 \\
\mathrm{ETF}=5 \\
\mathrm{ETAF}=2 \\
\mathrm{EA}=6 \\
\mathrm{~T}=19 \\
\mathrm{~A}=5 \\
\mathrm{EF}=6\end{array}$ & $\begin{array}{l}\mathrm{A} 1=17 \\
\mathrm{~A} 2=33 \\
\mathrm{~B} 1=121 \\
\mathrm{~B} 2=64 \\
\mathrm{C} 1=12 \\
\mathrm{C} 2=5 \\
\mathrm{~N}=144\end{array}$ \\
\hline 2 & & & $\begin{array}{l}\mathrm{K}=6.459 \\
p=0.011\end{array}$ & & & $\begin{array}{l}\mathrm{K}=8.002 \\
p=0.005\end{array}$ & & & & \\
\hline 9 & $\begin{array}{l}\mathrm{U}=8673.5 \\
p=0.000\end{array}$ & $\begin{array}{l}\mathrm{U}=14,442 \\
p=0.001\end{array}$ & $\begin{array}{l}\mathrm{K}=4.520 \\
p=0.033\end{array}$ & $\begin{array}{l}\mathrm{U}= \\
11.374 \\
p=0.001\end{array}$ & & & & & $\begin{array}{l}\mathrm{K}=11.972 \\
p=0.001\end{array}$ & $\begin{array}{l}\mathrm{K}= \\
12.509 \\
p=0.000 \\
\mathrm{~K}=4.293 \\
p=0.038\end{array}$ \\
\hline 12 & & & & & $\begin{array}{l}\mathrm{K}= \\
12.292 \\
p=0.000 \\
\mathrm{~K}=8.203 \\
p=0.004\end{array}$ & & & $\begin{array}{l}\mathrm{K}=3.975 \\
p=0.046\end{array}$ & $\begin{array}{l}\mathrm{K}=6.162 \\
p=0.013\end{array}$ & \\
\hline 6 & $\begin{array}{l}\mathrm{U}=9643.5 \\
p=0.001\end{array}$ & $\begin{array}{l}\mathrm{U}=14,562 \\
p=0.000\end{array}$ & & & & & $\begin{array}{l}U= \\
17315 \\
p=0.023\end{array}$ & & & $\begin{array}{l}\mathrm{K}= \\
12.777 \\
p=0.000\end{array}$ \\
\hline
\end{tabular}

Note: $\mathrm{G}=$ Gender; $\mathrm{F}=$ Female; $\mathrm{M}=$ Male; $\mathrm{LM}=$ One mother tongue; $2 \mathrm{LM}=$ More than one mother tongue; LM-E $=$ Spanish as only mother tongue; AELE2 = Years of study of the LE2; $1=$ From 1 to 3 years; $2=$ From 4 to 7 years; 3 = from 8 to 14 years; 4 = More than 14 years; $\mathrm{C}=$ Year of study; $\mathrm{C} 1=$ First year; $\mathrm{C} 2=\mathrm{Second}$ year; $\mathrm{C} 3$ = Third year; C4 = Fourth year; C5 = Fifth year; Tit = Degree; EI = Early Childhood Education; EP = Primary Education; ES = Social Education; DG = Double Degree; LCI = Languages in touch with during childhood; E = Spanish; ET = Spanish and Tamazight; ETA = Spanish, Tamazight, and Arabic; ETF = Spanish, Tamazight, and French; ETAF = Spanish, Tamazight, Arabic, and French; EA = Spanish and Arabic; EF = Spanish and French; ACLLE1 = Certification of language proficiency for the LE1; LE1 = First foreign language; $\mathrm{I}=$ English; $\mathrm{F}=$ French $\mathrm{P}=$ Portuguese; LPFDT = Languages in which parents and relatives speak to you; $\mathrm{T}=$ Tamazight; $\mathrm{A}=\mathrm{Arabic}$ CNRLE1 = Level acquired for the LE1 certification; A1 = A1 level; A2 = A2 level; B1 = B1 level; B2 = B2 level; C1 = $\mathrm{C} 1$ level; $\mathrm{C} 2$ = C2 level; $\mathrm{N}=$ None; $\mathrm{U}=$ Mann-Whitney test; $p=p$-value; $\mathrm{K}=$ Kruskal-Wallis test.

With respect to item 12, The learning style determines the way in which languages are learned, the participants are inclined, in a great majority, to believe that the learning style is determinant in language acquisition. Th variables that discriminate with respect to item 12 are the degree, languages in which parents and relatives speak to you, first foreign language. On the one hand, those enrolled in the degree in Primary Education agreed with its influence $(78.1 \%)$ as well as those enrolled in the degree in Social Education $(95.6 \%)$, a significant statistical difference confirmed by the Kruskal-Wallis test $(p=0.000)$. On the other hand, the subgroup that is enrolled in the Social Education degree represented the 95.6\%, and those enrolled in $\mathrm{f}$ the double degree represented the $82.8 \%$, who share their beliefs regarding this item, a difference validated by the Kruskal-Wallis test $(p=0.004)$. The languages in which parents and relatives speak to you ( $p=0.013), 81.7 \%$ of respondents had been exposed only to the Spanish language, and $92.9 \%$ of the respondents exposed to the combination of Spanish and Tamazight responded that they agree, with a difference of more than 11 points between the former and the latter. The first foreign language ( $p=0.046), 84.8 \%$ of those who chose English as their first foreign language, and $66.7 \%$ of those who opted for French equally agree (Table 4).

Finally, in the analysis of item 6, When the student is taught in the preferred sensory modality (visual, auditory, kinesthetic), better academic performance is obtained, it was found that the agree was mostly chosen, and there are significant statistical differences with respect to the following variables: (a) gender $(p=0.001), 82.5 \%$ of women and $66.7 \%$ of men, with a difference of more than 15 points between them; $(b)$ one mother tongue or more than one mother tongue $(p=0.000)$, a majority $(91.1 \%)$ of the bilingual respondents, and $73.7 \%$ of the monolingual Spanish speakers; (c) certification of language proficiency of the first foreign language ( $p=0.023), 75.5 \%$ of those in the subgroup have such an accreditation, and $85.4 \%$ of those do not have this certification; (d) reference level certification for the FL1 $(p=0.000)$, 
$41.2 \%$ of students who have level $\mathrm{A} 1$ and $87.9 \%$ who have $\mathrm{A} 2$, with a difference between the former and the latter of more than 46 points (Table 4).

\subsection{Dimension 3 Language Learning}

\subsubsection{Univariate Analysis}

We observed that in the responses to item 1 , It is no longer possible to learn a foreign language well beyond a certain age, a large majority $(79.1 \%)$ disagrees with the idea of the existence of sensitive periods, while a very low percentage $(13.6 \%)$ believes that after a certain age such learning is no longer possible, with a difference of more than 65 points.

Regarding item 4, You only really learn a foreign language when you interact in real situations, three quarters of the participants (75.6\%) think that social interaction is relevant for the mastery of a new language.

Regarding item 5, It is more difficult for a person who speaks a foreign language to lean others, three quarters (79.6\%) agree that the knowledge acquired in learning any foreign language does not hinder the learning of other languages.

As for item 7, Sufficient grammar and vocabulary must be learned before beginning to express oneself in a FL, the belief in the need to prioritize declarative learning, for example grammar or lexis, before starting to develop any linguistic activity in order to communicate adequately and fluently in the foreign language (and according to needs), is quite widespread (59.7\%) among the participants in this study. However, it is noted that slightly more than a third of the subjects (38.5\%) expressed their disagreement.

Finally, in the responses to item 11, Children should learn their native language before they start learning a foreign language otherwise they will not fully learn either on, more than half of the respondents (59.4\%) believe that the learning of a foreign language is conditional on the prior acquisition of the mother tongue, compared to almost a third of the respondents $(29.5 \%)$ who think the opposite (see Figure 3).

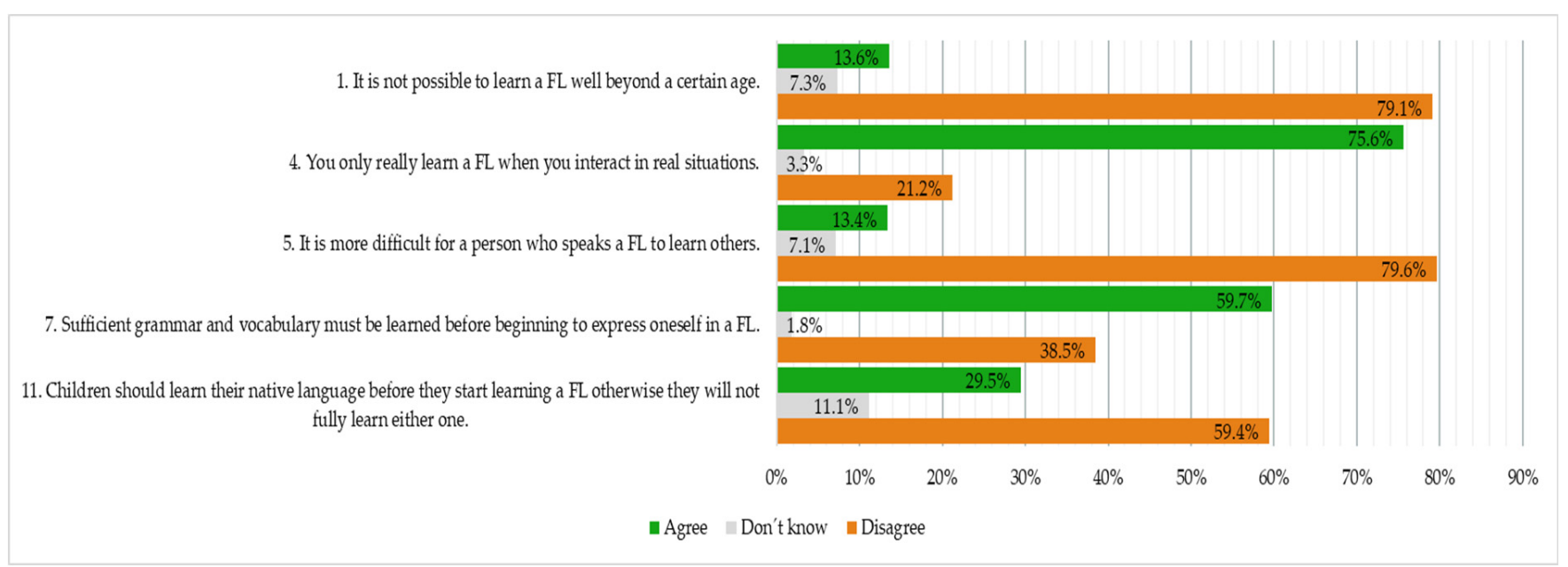

Figure 3. Frequency distribution of the 5 items that make up Dimension 3. Language learning.

\subsubsection{Bivariate Analysis}

We observed (Table 5) that there are more Disagree responses for item 1, It is no longer possible to learn a FL well beyond a certain age. There are also significant statistical differences in the analysis of the crossover between item 1 and the following descriptive variables: (a) language in contact during childhood, validated by the Kruskal-Wallis test $(p=0.007)$, $85.6 \%$ of the subjects exposed to the Spanish and Tamazight languages and $64.1 \%$ of those exposed to the Spanish, Tamazight, and Arabic languages, with a difference of more than 21 points; (b) FL1, ( $p=0.027$ ) (Table 5) all participants who reported having studied their first foreign language between 1 and 3 years and 71.7\% between 4 and 7 years; (c) year of study, confirmed by the Kruskal-Wallis test $(p=0.039), 82.1 \%$ of the students in their second 
year and $69.4 \%$ of those in their third year; (d) accreditation of language proficiency, endorsed by the Mann-Whitney test ( $p=0.003)$, almost three quarters $(74.2 \%)$ of those respondents who have a certification for their FL1 and $86 \%$ of those who do not, with a difference of more than 11 points (Table 5).

Table 5. Comparative statistics on Language learning.

\begin{tabular}{|c|c|c|c|c|c|c|c|c|c|c|c|}
\hline Items & G & LM/2LM & LR & AELE1 & $\mathrm{C}$ & Tit & LCI & ACLLE1 & LE1 & LE2 & LPFDT \\
\hline & $\begin{array}{l}F=325 \\
M=72\end{array}$ & $\begin{array}{l}\text { LM-E = } \\
186 \\
2 \mathrm{LM}= \\
211\end{array}$ & $\begin{array}{l}\mathrm{ML}= \\
305 \\
\mathrm{RE}=92\end{array}$ & $\begin{array}{l}1=16 \\
2=46 \\
3=194 \\
4=141\end{array}$ & $\begin{array}{l}\mathrm{C} 1=81 \\
\mathrm{C} 2=56 \\
\mathrm{C} 3=85 \\
\mathrm{C} 4=114 \\
\mathrm{C} 5=61\end{array}$ & $\begin{array}{l}\mathrm{EI}=82 \\
\mathrm{EP}=96 \\
\mathrm{ES}=91 \\
\mathrm{DG}= \\
128\end{array}$ & $\begin{array}{l}\mathrm{E}=188 \\
\mathrm{ET}=132 \\
\mathrm{ETA}=39 \\
\mathrm{ETF}=2 \\
\mathrm{ETAF}= \\
16 \\
\mathrm{EA}=5 \\
\mathrm{EF}=11 \\
\mathrm{EAF}=4\end{array}$ & $\begin{array}{l}\text { Yes }=252 \\
\text { No }=145\end{array}$ & $\begin{array}{l}I=362 \\
F=28 \\
P=7\end{array}$ & $\begin{array}{l}\mathrm{I}=34 \\
\mathrm{~F}=174 \\
\mathrm{Gl}=5 \\
\mathrm{P}=15 \\
\mathrm{~A}=12 \\
\mathrm{~N}=157\end{array}$ & $\begin{array}{l}E=262 \\
\mathrm{ET}=85 \\
\mathrm{ETA}=7 \\
\mathrm{ETF}=5 \\
\mathrm{ETAF}=2 \\
\mathrm{EA}=6 \\
\mathrm{~T}=1 \\
\mathrm{~A}=5 \\
\mathrm{EF}=6\end{array}$ \\
\hline 1 & & & & $\begin{array}{l}\mathrm{K}=4.897 \\
p=0.027\end{array}$ & $\begin{array}{l}\mathrm{K}=4.274 \\
p=0.039\end{array}$ & & $\begin{array}{l}\mathrm{K}=7.385 \\
p=0.007\end{array}$ & $\begin{array}{l}\mathrm{U}= \\
16701 \\
p=0.003\end{array}$ & & & \\
\hline 11 & & & $\begin{array}{l}\mathrm{U}= \\
10,008.5 \\
p=0.000\end{array}$ & & & & & $\begin{array}{l}U= \\
16092.5 \\
p=0.002\end{array}$ & & & \\
\hline 4 & $\begin{array}{l}\mathrm{U}= \\
10,358 \\
p=0.042\end{array}$ & $\begin{array}{l}\mathrm{U}= \\
15,912 \\
p=0.029\end{array}$ & & & & & & & & $\begin{array}{l}K= \\
10.088 \\
p=0.001\end{array}$ & $\begin{array}{l}\mathrm{K}=14.722 \\
p=0.000\end{array}$ \\
\hline 5 & & $\begin{array}{l}\mathrm{U}= \\
15,840 \\
p=0.015\end{array}$ & & & $\begin{array}{l}\mathrm{K}=5.479 \\
p=0.019 \\
\mathrm{~K}=7.509 \\
p=0.006\end{array}$ & & & & & & \\
\hline 7 & & & $\begin{array}{l}\mathrm{U}= \\
10,802 \\
p=0.000\end{array}$ & & & $\begin{array}{l}\mathrm{K}= \\
11.103 \\
p=0.001\end{array}$ & & $\begin{array}{l}\mathrm{U}= \\
17016 \\
p=0.030\end{array}$ & $\begin{array}{l}\mathrm{K}=6.888 \\
p=0.009\end{array}$ & & \\
\hline
\end{tabular}

Note: $\mathrm{G}=$ Gender; $\mathrm{F}=$ Female; $\mathrm{M}=$ Male; $\mathrm{LM}=$ one mother tongue; $2 \mathrm{LM}=$ more than one mother tongue; $\mathrm{LM}-\mathrm{E}$ $=$ Spanish as only mother tongue; $\mathrm{LR}=$ Place of residence; $\mathrm{ML}=$ Melilla; $\mathrm{RE}=$ Rest of Spain AELE1 = years of study of the LE1; 1 = from 1 to 3 years; 2 = from 4 to 7 years; $3=$ from 8 to 14 years; $4=$ more than 14 years; $\mathrm{C}$ = Year of study; C1 = First year; C2 = Second year; C3 = Third year; C4 = Fourth year; C5 = Fifth year; Tit = Degree; EI = Early Childhood Education; EP = Primary Education; ES = Social Education; DG = Double Degree; LCI = Languages in touch with during childhood; E = Spanish; ET = Spanish and Tamazight; ETA = Spanish Tamazight, and Arabic; ETF = Spanish, Tamazight, and French; ETAF = Spanish, Tamazight, Arabic, and French; $\mathrm{EA}=$ Spanish and Arabic; EF = Spanish and French; ACLLE1 = certification of language proficiency for the LE1 LE1 = first foreign language; $\mathrm{I}=$ English; F = French; $\mathrm{P}=$ Portuguese; $\mathrm{LE2}=$ second foreign language; $\mathrm{Gl}=\mathrm{German}$; $\mathrm{N}=$ None; LPFDT = languages in which parents and relatives speak to you; $\mathrm{T}=$ Tamazight; $\mathrm{A}=\mathrm{Arabic} ; \mathrm{U}=$ Mann-Whitney test; $p=p$-value; $\mathrm{K}=$ Kruskal-Wallis test.

Regarding item 11, Children should learn their mother tongue before starting to learn a FL, otherwise they won't learn any of the two completely, the Disagree response marks a significant statistical difference in relation to these variables: (a) place of residence, ratified by the Mann-Whitney test $(p=0.000), 53.4 \%$ of the residents in Melilla and $79.3 \%$ of those from other regions in Spain, with a difference of more than 25 points (Table 5); (b) reference level certification for the FL1, tested by the Kruskal-Wallis test ( $p=0.002), 63.1 \%$ of those respondents who have language training certification and $54.3 \%$ of those who do not have it (Table 5).

Regarding item 4, You only really learn a FL when you interact in real situations, there are significant statistical differences in the agree responses regarding gender, one mother tongue or more than one mother tongue, and languages in which parents and relatives speak to you (Table 5). In (a) gender, confirmed by the Mann-Whitney test $(p=0.042)$, more than half of the women $(77.8 \%)$ and $65.3 \%$ of men, with a difference of more than 12 points between them. In (b) one mother tongue or more than one mother tongue $(p=0.029), 72.1 \%$ of the monolingual Spanish speakers and $82.2 \%$ of those with more than one mother tongue, with a difference of 10 points. In (c) languages in which parents and relatives speak to you ( $p$ $=0.000$ ), in this case, $72.1 \%$ of the participants indicated (Table 5 ), on the one hand, that they only speak the Spanish language and, on the other hand, $91.8 \%$ of those indicated that they speak the Spanish and Tamazight languages, with a difference of more than 19 points between them; (d) FL2 ( $p=0.001$ ), 55.9\% of the participants whose second foreign language is English and $81 \%$ of those with French as their FL2. 
Regarding item 5, For a person who speaks a FL it is more difficult to learn others, there is a significant statistical difference $(p=0.015)$. In fact, three quarters $(76 \%)$ of those whose only mother tongue is Spanish believe that knowing a foreign language facilitates language learning in the same way as those who are bilingual $(86.7 \%)$, with a difference of 10 points. The same applies for the variable year of study subgroup of respondents in their first year $(77.8 \%)$, second year $(92.9 \%)$, and third year $(74.1 \%)$, with a difference of 19 points between those in their second year and third year. These differences are statistically validated by the Kruskal-Wallis test in both cases ( $p=0.019$ and $p=0.006$, respectively) (Table 5).

Finally, in the analysis of item 7, It is necessary to learn sufficient grammar and vocabulary before starting to express oneself in a FL, there are significant statistical differences between those who agree with the fact that it is necessary to learn grammar and vocabulary before expressing themselves in the new target language in the following variables: (a) FL1, indicated by the Kruskal-Wallis test $(p=0.009)$, more than half $(61.6 \%)$ of the respondents study English as their FL1, and 35.7\% of the respondents study French as their FL1; (b) place of residence $(p=0.000), 65.2 \%$ of those reside in Melilla and $41.3 \%$ of those are from other parts of Spain. However, regarding the variable (c) degree, 53.9\% of the participants enrolled in the double degree and $33 \%$ of the students in the Primary Education degree believe that it is not necessary to wait to have sufficient grammatical and lexical knowledge to communicate in a foreign language, compared to less than $10 \%$ of those enrolled in the Social Education degree $(p=0.001)$ (Table 5). For variable (c) reference level certification for the FL1, evaluated by the Mann-Whitney test $(p=0.030), 42.5 \%$ of those who have a language training certification for their FL1 and 32.9\% of those who do not have it also expressed their disagreement with the statement, with a difference of 10 points (Table 5).

The responses infer the belief or disbelief of the students regarding the myth expressed in the items. It should be noted that the option selected by the respondents does not imply that they have discerned whether it concerns a neuromyth or a neuroscientific fact; the response only evidences the acceptance or not of what is stated in the item. However, all options have been interpreted in Figure 4 to demonstrate whether they responded correctly, incorrectly, or whether they implicitly recognized their lack of knowledge regarding the topics treated in the item.

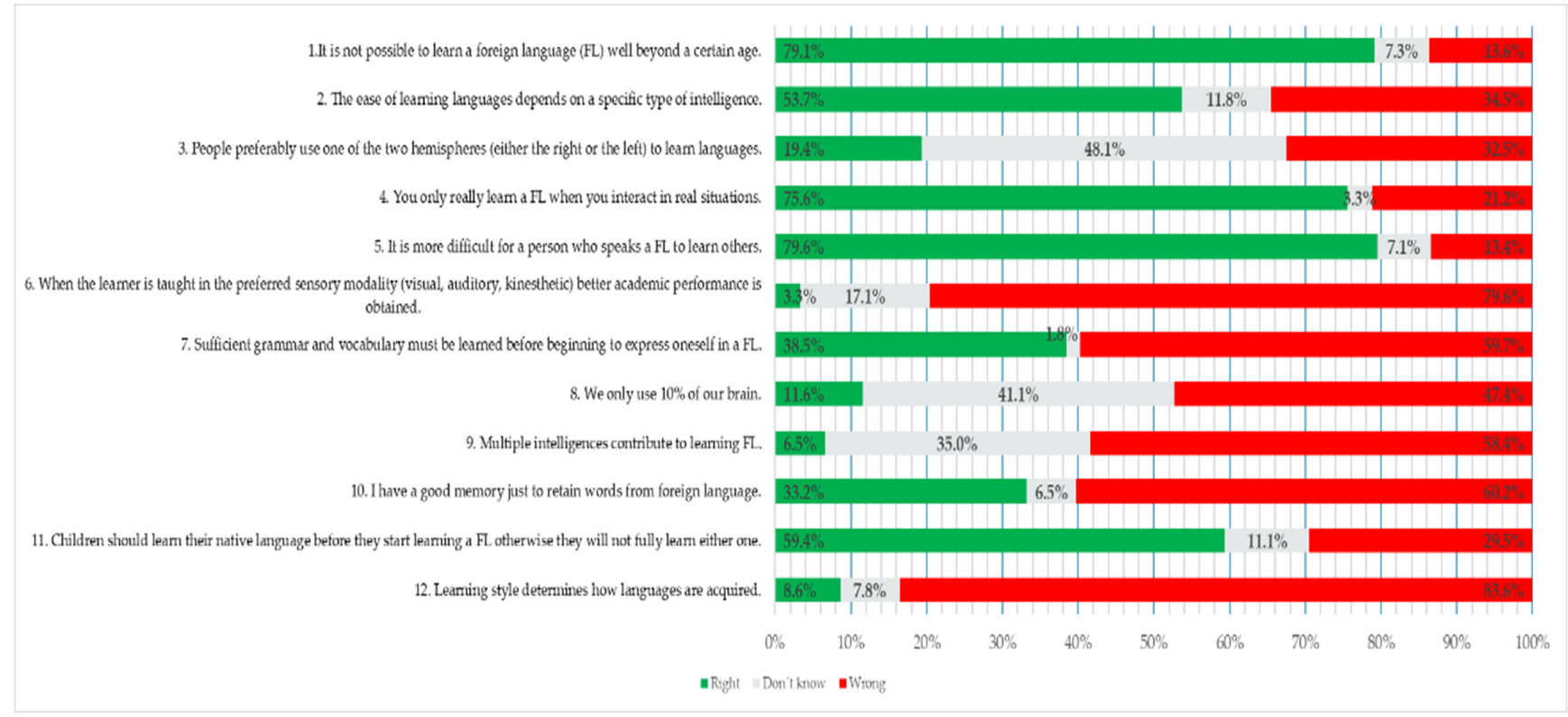

Figure 4. Responses by the study participants showing whether they responded correctly, incorrectly, or whether they did not know the answer. 


\section{Discussion}

Deepening the concepts that the students, future teachers, have regarding the neuroscience of language learning is of paramount importance to optimize their subsequent professional development. Thus, this exploratory study examines the linguistic context of preservice teacher training at the Melilla campus of the University of Granada, as well as the beliefs and conceptions that these multilingual learners have about educational neuromyths and language learning.

The results indicate that a high percentage of respondents (53.1\%) have more than one mother tongue, predominantly Spanish and Tamazight (39.8\%), and reside in Melilla. Almost all of them (91.2\%) have studied a first foreign language, generally English, throughout their preuniversity education, and $43.8 \%$ of the respondents have chosen French as their second foreign language. Only $30.5 \%$ of them have a B1 level certification of their first foreign language according to the CEFR [50].

Studies in different contexts on the prevalence of neuromyths among teachers are numerous [42,44], such as those collected by Masson et al. [39], have been conducted on the basis of questionnaires developed or adapted for this purpose [54,55]. In Switzerland, Tardif et al. [59] carried out these studies with preservice teachers and inservice teachers. In Spain, the work on the group of future teachers by Fuentes and Risso [60] stands out, but we have not found any studies describing the entrenchment or overcoming of myths about the functioning of the brain and language learning in multicultural contexts and in multilingual students, as in this present paper.

In the questionnaire for this research study, we took as a reference the neuromyths collected by the OECD $[45,46]$ and those that have been the subject of other research, such as the systematic review of the persistence of these in education carried out by Torrijos-Muelas et al. [41] on neuroplasticity, learning styles, multiple intelligences, hemispheric dominance, the use of only $10 \%$ of the brain, and critical periods. This is a key question if we consider that previous research studies [61] demonstrated the dominance of the left hemisphere for language processing and the dominance of the right one for emotional prosody processing during the listening comprehension of language. Breakthroughs in science have shown that the brain builds a model of the body's state from sensory inputs, and all inputs, perceptions, thoughts, and actions will be affected by momentary changes in the individual's internal state, and the states they will affect the dynamics of neural processing [62].

Regarding items 3 and 8 (dimension 1), more than $40 \%$ of the respondents showed their lack of knowledge, since one third gave the wrong answer on the general functioning of the brain, and almost half admitted they did not know how to respond to this item. With respect to item 8 , around $50 \%$ accepts the false idea of the use of $10 \%$ of the brain, to which the $41 \%$ who do not know the answer can be added. The responses undoubtedly indicate the prevalence of the neuromyths, noted by the OECD $[45,46]$ and other research studies [39-41], as previously mentioned.

On the other hand, the results show that the correct answers of the participants, with an acceptance of the items above $50 \%$, referring to brain plasticity and the acquisition of language learning (item 1). As for other myths related to dimension 3, the respondents recognized the need for social interaction to foster effective language learning (item 4), and they admitted that the knowledge of a foreign language does not hinder learning new languages (item 5) and that simultaneous learning of the mother tongue and other foreign language(s) at an early age does not interfere with the mastery of those languages, as indicated in item 11. According to Rato, Abreu, and Castro-Calda [63], this myth affirms the false idea that languages compete, and that the first language must be learnt properly before learning other language(s). Furthermore, this study affirms that the participants have overcome the neuromyths stated by Paredes [48]. 
As for items 6, 7, 9, and 10, the participants gave wrong answers, over 58\%, which indicates a lack of knowledge of neuroeducation findings in relation to the statements presented in these items. This is consistent with the literature referenced in this paper. The response to item 10 shows a lack of knowledge with respect to memory functioning in learning processes, a key question for the Neurolinguistic Approach (NLA) of learning of first and second foreign languages [26], which is based on the theories of Paradis [33-35,64] about the implicit and explicit memory. Item 6, on teaching in the student's preferred sensory modality (visual, auditory, and kinesthetic), was almost unanimously accepted $(80 \%)$, receiving, as in any other research with teachers [42,44], although not with students, a general consensus, which shows the prevalence of the neuromyth. However, the response to item 6 contrasts with that given to item 2, The ease of learning languages depends on a specific type of intelligence. This may be explained by the ambiguous interpretation of the term 'specific intelligence', which should be clarified by complementing this research with other qualitative research, e.g., by means of a personalized interview seeking clarification and a deeper understanding. Similarly, the wrong answer to item 7 indicates the prevalence of another false belief, noted by Germain $[27,28]$, which implies considering it necessary to acquire formal knowledge (lexis and grammar) before developing oral communication in the target language, which goes against the fundamental principles of the Neurolinguistic Approach, which advocates starting from authentic oral communication in learning foreign and second languages. For the participants, multiple intelligences seem to be decisive in language learning (item 9), ratifying the persistence and scope of this erroneous belief. This educational neuromyth may have been fostered among teachers through the methodological guides of foreign and second language teaching manuals based on Gardner's Multiple Intelligences theory [65]. These results are, frankly, relevant, as they are key arguments to face the teaching process based on scientific facts, such as that the decoding of the brain between languages has, in turn, the potential to provide new knowledge about how our brain represents various languages. Focusing teaching on neural representations to understand the cortical representations of different languages, based on learning algorithms, which allow the capturing of spatial data and temporal information as language processing develops in real time, thus allowing the decoding of the brain in other languages [66]. This is the current line of neuroscience research on the decoding of information in different languages. The results obtained in this study can be a beacon that guides the conceptual training processes of language teachers in training based on the great achievements of neuroscience. Therefore, demonstrating the existence of neuromyths is only one part of the educational process. Today, it is essential to understand how the neuroscience of language learning works in order to develop programs in which scientific progress and didactic methodologies converge.

\section{Conclusions}

The exploratory study has made it possible to describe the sample, made up of future educators and multilingual teachers in a specific geographical context, characterized as being multicultural and multilingual. It aims, among others, to find out the prevalence of educational neuromyths in relation to language learning.

This paper does not seek to conclude an exploratory objective on misconceptions. It intends to be a scientific argument that allows us to undertake an educational exercise of knowledge about neuroscience applied to language teaching.

The task of teaching is clearly to demystify widely held misconceptions, but, as demonstrated in the scientific literature reviewed in this paper, there is evidence that for some education professionals myths persist. In this study, no statistically significant differences were found in the item responses of those with only one mother tongue compared to those with more than one. It is noteworthy that the implicit neuromyths in the items of dimensions 1 and 2 prevail among the participants. However, in dimension 3 , which refers to the neuromyths concerning language learning, the results indicate an inverse trend. This might be related to the multilingual coding experience of the 
sample in this study, since multilingualism is simply a parametric variation in the natural language faculty, and it is possible to acquire several languages simultaneously at any age [67]. This language capacity is the one that is hampered by the perseverance of myths that, as evidenced by the answers in dimension 3, lose their influence when it comes to people who have acquired more than one language during their development. Hence the importance of delving into the study of false beliefs about the functioning of the brain and language learning.

Much remains to be accomplished in this line of work. This contribution is, therefore, a proactive proposal inspired by academic and scientific objectives, aspirations, and ambitions. Science has shown that language appeared at a late stage in the evolution of Homo sapiens along with the executive functions that allow us to plan our behavior, which includes learning. If we learn how our brain works, we will surely learn how to teach to learn, which is one of the fundamental missions of education.

Author Contributions: Conceptualization, M.J.C.L., C.A.S.G. and L.I.N.; Data curation, A.N.R., M.J.C.L., C.A.S.G. and L.I.N.; Formal analysis, A.N.R., M.J.C.L., C.A.S.G. and L.I.N.; Funding acquisition, A.N.R., M.J.C.L., C.A.S.G. and L.I.N.; Investigation, A.N.R., M.J.C.L., C.A.S.G. and L.I.N.; Methodology, A.N.R., M.J.C.L., C.A.S.G. and L.I.N.; Project administration, A.N.R., M.J.C.L., C.A.S.G. and L.I.N.; Resources, A.N.R., M.J.C.L., C.A.S.G. and L.I.N.; Software, A.N.R., M.J.C.L., C.A.S.G. and L.I.N.; Supervision, A.N.R., M.J.C.L., C.A.S.G. and L.I.N.; Validation, A.N.R., M.J.C.L., C.A.S.G. and L.I.N.; Visualization, A.N.R., M.J.C.L., C.A.S.G. and L.I.N.; Writing - original draft, A.N.R., M.J.C.L., C.A.S.G. and L.I.N.; Writing - review \& editing, A.N.R., M.J.C.L., C.A.S.G. and L.I.N. All authors have read and agreed to the published version of the manuscript.

Funding: This research received no external funding.

Institutional Review Board Statement: The study was carried out in accordance with the Declaration of Helsinki, which is taken into consideration by our institution, the University of Granada, by its ethical committee on human research (https://investigacion.ugr.es/apoyo/comite-etica). In response to this, the objectives of the research were made explicit to all participants, their voluntary participation was counted on and the anonymity of their responses and data has been ensured, as well as their treatment for exclusively statistical purposes, derived from the research.

Informed Consent Statement: Informed consent was obtained from all subjects involved in the study, who were informed of their voluntary participation in it, ensuring the anonymity of their responses and data, as well as their treatment exclusively for the development of this research. The following was specified in the questionnaire: "The personal information requested will remain anonymous and will only be used for research and statistical purposes. Participation in the study is entirely voluntary".

Data Availability Statement: The data collected in the questionnaires in Excel format and the analyzes carried out in SPSS have not been posted on the MDPI platform, or in any internet file to guarantee the anonymity of the participants.

Conflicts of Interest: The authors declare no conflict of interest.

\section{Appendix A. Questionnaire on Multilingualism and Foreign Language Learning}

The purpose of this questionnaire is to find out what you think about multilingualism and language learning.

Your contribution is very valuable.

The personal information requested will remain anonymous and will only be used for research and statistical purposes. Participation in the study is entirely voluntary.

Please remember that, with your cooperation, you will help the scientific community in improving educational practices in the classroom.

\section{Personal information}

Degree and Course: Gender: Male $\square$ Female:

Place and country of residence: Nationality:

What is your mother tongue? 
Spanish $\square$ French $\square$ Arabic $\square$ Tamazight $\square$ English $\square$ Other:

What is your second mother tongue (if you have one)?

Spanish $\square$ French $\square$ Arabic $\square$ Tamazight $\square$ English $\square$ Other:

What language(s) were you in contact with during your childhood?

Spanish $\square$ French $\square$ Arabic $\square$ Tamazight $\square$ English $\square$ Other:

In which language(s) do your parents and close relatives speak to you?

Spanish $\square$ French $\square$ Arabic $\square$ Tamazight $\square$ English $\square$ Other:

Which languages do your close relatives speak between them?

Spanish $\square$ French $\square$ Arabic $\square$ Tamazight $\square$ English $\square$ Other:

Is there language switching in your environment when emotional, place or activity changes take place? Yes $\square$ No

If this is the case, which languages are alternated?

Spanish $\square$ French $\square$ Arabic $\square$ Tamazight $\square$ English $\square$ Other:

What is your first foreign language (FL1)?

French $\square$ English $\square$ Other:

How many years have you been studying your FL1?

Place and country of study of the FL1:

Do you have a FL1 certification? Yes $\square$ No $\square$

If you do, which level did you obtain for this according to the CEFR?

A1 $\square$ A2 $\square$ B1 $\square$ B2 $\square$ C1 $\square$ C2 $\square$

How difficult are the following skills in your FL1?

1: Not difficult 2: Somewhat difficult 3: Very difficult 4: I'm not able

Oral interaction

Oral expression

Reading comprehension

Writing

Listening

What is your second foreign language (FL2)?

French $\square$ English $\square$ Other:

How many years have you been studying your FL2?

Place and country of study of the FL2:

Do you have a FL2 certification? Yes $\square$ No $\square$

If you do, which level did you obtain for this according to the CEFR?

A1 $\square$ A2 $\square$ B1 $\square$ B2 $\square$ C1 $\square$ C2 $\square$

How difficult are the following skills in your FL2?

1: Not difficult 2: Somewhat difficult 3: Very difficult 4: I'm not able

Oral interaction

Oral expression

Reading comprehension

Writing

Listening

Read the statements below carefully and express your opinion by ticking either Agree (if you are in favour), Disagree (if you are against) or Don't know. 
Table A1. Questionnaire items and acceptance degree.

\begin{tabular}{l}
\hline \\
\hline 1. It is no longer possible to learn a foreign language (FL) well beyond a \\
certain age. \\
2. The ease of learning languages depends on a specific type of intelligence. \\
3. People preferably use one of the two hemispheres (either the right or the left) \\
to learn languages. \\
4. You only really learn a FL when you interact in real situations. \\
5. It is more difficult for a person who speaks a FL to learn others. \\
6. When the learner is taught in the preferred sensory modality (visual, auditory, \\
kinesthetic) better academic performance is obtained. \\
7. Sufficient grammar and vocabulary must be learned before beginning to \\
express oneself in a FL. \\
8. We only use 10\% of our brain. \\
9. Multiple intelligences contribute to learning FL. \\
10. I have a good memory just to retain words from foreign language. \\
11.Children should learn their native language before they start learning a FL \\
otherwise, they will not fully learn either one. \\
12. Learning style determines how languages are acquired.
\end{tabular}

\section{Appendix B}

Table A2. Justification for the Chosen Items and Adaptation Based on Authors.

\begin{tabular}{ll}
\hline \multicolumn{1}{c}{ Items } & \multicolumn{1}{c}{ Based on } \\
\hline $\begin{array}{l}\text { 1. It is no longer possible to learn a foreign language (FL) } \\
\text { well beyond a certain age. }\end{array}$ & $\begin{array}{l}\text { Adapted from [54] Horwitz, 1988, “Table 2. Foreign Language } \\
\text { Aptitude", item "1. It is easier for children than aduts to learn a foreign } \\
\text { language", p. 285 }\end{array}$ \\
\hline & $\begin{array}{l}\text { Adapted from [7] Craig et al., 2021, "Appendix Percent of Correct } \\
\text { Answers to Statements". "Basing instructional strategies on multiple } \\
\text { 2. The ease of learning languages depends on a specific } \\
\text { type of intelligence. }\end{array}$ \\
& $\begin{array}{l}\text { intelligences (e.g., linguistic, musical, and interpersonal intelligence) is } \\
\text { not supported by research", p. 137. }\end{array}$ \\
\hline
\end{tabular}

Adapted from [55] Herculano-Houzel, 2002, “Table 1. Relation of all 95 assertions in the order they appeared in the questionnaire" Assertion "72. Being right- or left-handed is a matter of being, respectively, left or right brain hemisphere dominant", p. 101.

Adapted from [39] Masson, 2015, "Tableau 1. Neuromythes les plus fréquents chez les enseignants". "Dominance hémisphérique. Des

3. People preferably use one of the two hemispheres (either the right or the left) to learn languages. différences de dominance hémisphérique (cerveau gauche ou cerveau droit) peuvent aider à expliquer les différences observées parmi les apprenants», p. 15.

Adapted from [42] Dekker et al., 2012, “Table 1. Correctness of responses for each myth assertion". "Differences in hemispheric dominance (left brain, right brain) can help explain individual differences amongst learners", p. 9

4. You only really learn a FL when you interact in real situations.

5. It is more difficult for a person who speaks a FL to learn others.
Adapted from [54] Horwitz, 1988, "Table 3. The Nature of Language Learning", item "11. It is better to learn a foreign language in the foreign country", p. 288.

Adapted from [54] Horwitz, 1988, “Table 2. Foreign Language Aptitude", item "10. It is easier for someone who already speaks a foreign language to learn another one", p. 287 
Table A2. Cont.

\section{Items}

6. When the learner is taught in the preferred sensory modality (visual, auditory, kinesthetic) better academic performance is obtained.
Based on

Gathered from [39] Masson, 2015, “Tableau 1. Neuromythes les plus fréquents chez les enseignants". "Styles d'apprentissage. Les élèves apprennent mieux, lorsqu'ils reçoivent l'information dans leur style d'apprentissage préféré (ex. auditif, visuel ou kinesthésique)", p. 15. Adapted from [42] Dekker et al., 2012, "Table 1. Correctness of responses for each myth assertion". "Individuals learn better when they receive information in their preferred learning style (e.g., auditory, visual, kinesthetic)", p. 9

Adapted from [54] Horwitz, 1988, “Table 3. The Nature of Language Learning", item "16. Learning a foreign language is mostly a matter of learning a lot of new vocabulary words", p. 288; and adapted from [54] Horwitz, 1988, "Table 3. The Nature of Language Learning", item “20. Learning a foreign language is mostly a matter of learning a lot of grammar rules", p. 288.

Gathered from [55] Herculano-Houzel, 2002, “Table 1. Relation of all 95 assertions in the order they appeared in the questionnaire". Assertion "68. We usually utilize only $10 \%$ of our brain", p. 10.

Gathered from [39] Masson, 2015, "Tableau 1. Neuromythes les plus fréquents chez les enseignants". "10\% Nous utilisons à peine que $10 \%$ de notre cerveau", p. 15

Adapted from [9] Craig et al., 2021, “Appendix Percent of Correct Answers to Statements". "Basing instructional strategies on multiple intelligences (e.g., linguistic, musical, and interpersonal intelligence) is not supported by research.", p. 137.

Adapted from [55] Herculano-Houzel, 2002, “Table 1. Relation of all 95 assertions in the order they appeared in the questionnaire". Assertion "33. Memory is stored in a net of many cells scattered throughout the brain", p. 100

Adapted from [42] Dekker et al., 2012, "Table 1. Correctness of responses for each myth assertion".

"Children must acquire their native language before a second language is learned. If they do not do so neither language will be fully acquired", p. 9

Adapted from [39] Masson, 2015, "Tableau 1. Neuromythes les plus fréquents chez les enseignants". "Styles d'apprentissage", p. 15. Adapted from [42] Dekker et al., 2012, "Table 1. Correctness of responses for each myth assertion". "Individual learners show preferences for the mode in which they receive information (e.g., visual, auditory, kinesthetic).", p. 9

\section{References}

1. Jones, E.G.; Mendell, L.M. Assessing the decade of the brain. Science 1999, 284, 739. [CrossRef]

2. Dubinsky, J.M.; Guzey, S.S.; Schwartz, M.S.; Roehrig, G.; MacNabb, C.; Schmied, A.; Hinesley, V.; Hoelscher, M.; Michlin, M.; Schmitt, L.; et al. Contributions of neuroscience knowledge to teachers and their practice. Neuroscientist 2019, 25, 394-407. [CrossRef] [PubMed]

3. Ansari, D.; De Smedt, B.; Grabner, R.H. Neuroeducation-A critical overview of an emerging field. Neuroethics 2012, 5, 105-117. [CrossRef]

4. Ansari, D.; Konig, J.; Leask, M.; Tokuhama-Espinosa, T. Developmental cognitive neuroscience: Implications for teachers' pedagogical knowledge. In Pedagogical Knowledge and the Changing Nature of the Teaching Profession; Guerriero, S., Ed.; OECD Publishing: Paris, France, 2017; pp. 195-222. [CrossRef]

5. Geake, J. Neuromythologies in education. Educ. Res. 2008, 50, 123-133. [CrossRef]

6. Digilio, R. Comunicazione scientifica e brain branding. In Ricerche Di Psicologia; Franco Angeli: Milano, Italy, 2017 ; pp. $401-416$.

7. Craig, H.L.; Wilcox, G.; Makarenko, E.M.; MacMaster, F.P. Continued Educational Neuromyth Belief in Pre-and In-Service Teachers: A Call for De-Implementation Action for School Psychologists. Can. J. Sch. Psychol. 2021, 36, 127-141. [CrossRef] 
8. Fuller, J.K.; Glendening, J.G. The neuroeducator: Professional of the future. Theory Into Pract. 1985, 24, 135-137. [CrossRef]

9. Merchán Morales, V. La neurodidáctica, una revisión conceptual. In Innovación Psicológica: Salud, Educación y Cultura; Riaño Garzón, M.E., Torrado Rodríguez, J.L., Díaz Camargo, E.A., Espinosa Castro, J.F., Eds.; Ediciones Universidad Simón Bolívar: Barranquilla, Colombia, 2018; pp. 153-176.

10. Bruer, J.T. Education and the brain: A bridge too far. Educ. Res. 1997, 26, 4-16. [CrossRef]

11. Sahay, A.; Wilson, D.A.; Hen, R. Pattern separation: A common function for new neurons in hippocampus and olfactory bulb. Neuron 2011, 70, 582-588. [CrossRef]

12. De La Rosa-Prieto, D.; Saiz-Sanchez, D.; Ubeda-Banon, I.; Flores-Cuadrado, A. Neurogenesis, Neurodegeneration, Interneuron Vulnerability, and Amyloid-B in the olfactory Bulb of APP/PS1 Mouse Model of Alzheimer's Disease. Front. Neurosci. 2016, 10, 227. [CrossRef]

13. Boldrini, M.; Fulmore, C.A.; Tartt, A.N.; Simeon, L.R.; Pavlova, I.; Poposka, V.; Rosoklija, G.B.; Stankov, A.; Arango, V.; Dwork, A.J.; et al. Human hippocampal neurogenesis persists throughout aging. Cell Stem Cell 2018, 22, 589-599. [CrossRef]

14. Howard-Jones, P.A.; Varma, S.; Ansari, D.; Butterworth, B.; De Smedt, B.; Goswami, U.; Laurillard, D.; Thomas, M.S. The principles and practices of educational neuroscience: Comment on Bowers. Psychol. Rev. 2016, 123, 620-627. [CrossRef]

15. Feiler, J.B.; Stabio, M.E. Three pillars of educational neuroscience from three decades of literature. Trends Neurosci. Educ. 2018, 13, 17-25. [CrossRef]

16. Lichtheim, L. On aphasia. Brain 1885, 7, 433-484. [CrossRef]

17. Gajardo-Vidal, A.; Lorca-Puls, D.L.; Hope, T.M.; Parker Jones, O.; Seghier, M.L.; Prejawa, S.; Crinion, J.P.; Leff, A.P.; Green, D.W.; Price, C.J. How right hemisphere damage after stroke can impair speech comprehension. Brain 2018, 141, 3389-3404. [CrossRef] [PubMed]

18. Chang, Y.N.; Lambon Ralph, M.A. A unified neurocomputational bilateral model of spoken language production in healthy participants and recovery in poststroke aphasia. Proc. Natl. Acad. Sci. USA 2020, 117, 32779-32790. [CrossRef] [PubMed]

19. Schenk, S.; Waldie, K.; Grimshaw, G. Cognitive and affective neuroscience: Approaches and applications. J. R. Soc. N. Z. 2021, 51, 1-3. [CrossRef]

20. Hamm, J.P. A discussion on the research process and illusory line motion. J. R. Soc. N. Z. 2021, 51, 51-80. [CrossRef]

21. Machado, L. Understanding cognition and how it changes with aging, brain disease, and lifestyle choices. J. R. Soc. N. Z. 2021, 51, 128-142. [CrossRef]

22. Kim, Y.K.; Han, K.M. Neural substrates for late-life depression: A selective review of structural neuroimaging studies. Prog. Neuro-Psychopharmacol. Biol. Psychiatry 2021, 104, 110010. [CrossRef]

23. Ching, F.N.; So, W.W.; Lo, S.K.; Wong, S.W. Preservice Teachers' Neuroscience 881 Literacy and Perceptions of Neuroscience in Education: Implications for Teacher Education. Trends Neurosci. Educ. 2020, 21, 100144. [CrossRef]

24. Huc, P.; Vincent-Smith, B. Naissance de la neurodidactique. Le Français Dans Le Monde 2008, 357, 30-31.

25. Huc, P.; Vincent-Smith, B. Neurodidactique, Imagerie Cérébrale Fonctionnelle et Langues secondes. Enjeux et Applications Pédagogiques, 1st ed.; Éditions Universitaires Européennes: Saarbrücken, Germany, 2011.

26. Germain, C.; Netten, J. Fondements d'une aproche transdisciplinaire en FLE/FL2: Le français intensif au Canada. In Cahier de Français Contemporaine 10. Pluralité des Langues et des Supports: Descriptions et Aproches Didactiques; Pugibet, V., Gettliffe-Grant, N., Coords, Eds.; ENS Éditions: Lyon, France, 2005; pp. 13-33.

27. Germain, C.; Jourdan-Otsuka, R.; Gladys, B. Developpement récents de l'approche neurolinguistique (ANL). Revue Japonaise de Didactique du Français 2018, 15, 21-37.

28. Germain, C. L'approche Neurolinguistique (ANL): Foire Aux Questions; Myosotis Presse: Longueuil, QC, Canada, 2017.

29. Cummins, J. The entry and exit fallacy in bilingual education. In An Introductory Reader to the Writings of JIM Cummins; Baker, C., Hornberger, N.H., Eds.; Multilingual Matters: Bristol, UK, 2001; pp. 110-138.

30. Damasio, A.; Damasio, H. Le cerveau et le langage. Pour la Science 1997, 17, 8-15.

31. Cummins, J.; Swain, M. Bilingualism in Education: Aspects of Theory, Research, and Practice; Longman: London, UK, 1986.

32. Vygotski, L.S. Pensée et Langage; Editions Sociales: Paris, France, 1985.

33. Paradis, M. Neurolinguistic aspects of implicit and explicit memory: Implications for bilingualism and SLA. In Implicit and Explicit Learning of Language; Ellis, N.C., Ed.; Academic Press: London, UK, 1994; pp. 393-420.

34. Paradis, M. A Neurolinguistic Theory of Bilingualism; John Benjamins: Amsterdam, The Netherlands, 2004.

35. Paradis, M. Declarative and Procedural Determinants of Second Languages; John Benjamins: Amsterdam, The Netherlands, 2009.

36. Ellis, N. Language Acquisition Just Zipf's Right Along. Université du Québec à Montréal: Montréal, QC, Canada, 2011.

37. Segalowitz, N. Cognitive Bases of Second Language Fluency; Routledge: New York, NY, USA, 2010.

38. Paredes, M.J. El aprendizaje de lenguas desde una perspectiva neurolingüística. Sabir. Int. Bull. Appl. Linguist. 2020, 1, 177-197. [CrossRef]

39. Masson, L. Les apports de la neuroéducation à l'enseignement: Des neuromythes aux découvertes actuelles. Approch. Neuropsychol. Des Apprentiss. Chez L'enfant. A.N.A.E. 2015, 134, 11-22.

40. Ferrero, M.; Garaizar, P.; Vadillo, M.A. Neuromyths in education: Prevalence among Spanish teachers and an exploration of cross-cultural variation. Front. Hum. Neurosci. 2016, 10, 496. [CrossRef]

41. Torrijos-Muelas, M.; González-Villora, S.; Bodoque-Osma, A.R. The Persistece of Neuromyths in the Educational Settings: A Systematic Review. Front. Psychol. 2021, 11, 591923. [CrossRef] 
42. Dekker, S.; Lee, N.C.; Howard-Jones, P.A.; Jolles, J. Neuromyths in education: Prevalence and predictors of misconceptions among teachers. Front. Psychol. 2012, 3, 429. [CrossRef] [PubMed]

43. Goswami, U. Neuroscience and education: From research to practice? Nat. Rev. Neurosci. 2006, 7, 406-413. [CrossRef] [PubMed]

44. Howard-Jones, P.A. Neuroscience and education: Myths and messages. Nat. Rev. Neurosci. 2014, 15, 817-824. [CrossRef] [PubMed]

45. Organisation for Economic Co-operation and Development (OECD). Understanding the Brain towards a New learning Science; OECD Publishing: Paris, France, 2002.

46. Centre for Educational Research and Innovation and Organization for Economic Co-operation and Development (OECD). Understanding the Brain: The Birth of a Learning Science; OECD: Paris, France, 2007.

47. Pasquinelli, E. Neuromyths: Why do they exist and persist? Mind Brain Educ. 2012, 6, 89-96. [CrossRef]

48. Arnon, I.; Christiansen, M.H. The role of multiword building blocks in explaining L1-L2 differences. Top. Cogn. Sci. 2017, 9 , 621-636. [CrossRef] [PubMed]

49. Couëtoux-Jungman, F.; Wendland, J.; Aidane, É.; Rabain, D.; Plaza, M.; Lécuyer, R. Bilingüisme, plurilinguisme et petite enfance: Intérêt de la prise en compte du contexte linguistique de l'enfant dans l'évaluation et le soin des difficultés de développement précoce. Devenir 2010, 22, 293-307. [CrossRef]

50. Council of Europe. Common European Framework of Reference for Languages: Learning, Teaching, Assessment; University Press: Cambridge, The Netherlands, 2001.

51. Council of Europe. Common European Framework of Reference for Languages: Learning, Teaching, Assessment, Companion Volume with New Descriptors; Council of Europe Publishing: Strasbourg, France, 2018.

52. Bertrand, I.; Christ, H. Propositions pour un enseignement des langues élargi. Lang. Mod. 1990, 3, 95-104.

53. Pulido, M.F. Native language inhibition predicts more successful second language learning: Evidence of two ERP pathways during learning. Neuropsychologia 2021, 152, 107732. [CrossRef] [PubMed]

54. Horwitz, E.K. The Beliefs about Language Learning of Beginning University 960 Foreign Language Students. Mod. Lang. J. 1988, 72, 283-294. [CrossRef]

55. Herculano-Houzel, S. Do you know your brain? A survey on public neuroscience 966 literacy at the closing of the decade of the brain. Neuroscientist 2002, 8, 98-110. [CrossRef] [PubMed]

56. Rodríguez, A.; Gallego, J.L. Aprendiendo a escribir durante la enseñanza obligatoria, ¿deseo o realidad? Calidoscopio 2017, 15, 106-125. [CrossRef]

57. Rodríguez, A. Disfunciones sintácticas encontradas en textos narrativos producido por alumnos con baja visión e invidencia. Rev. De Educ. Del MEC 2007, 343, 431-451.

58. Rodríguez, A.; Caurcel, M.J.; Gallardo-Montes, C.P.; Crisol, E. Psychometric Properties of the Questionnaire "Demands and Potentials of ICT and Apps for Assisting People with Autism" (DPTIC-AUT-Q). Educ. Sci. 2021, 11, 586. [CrossRef]

59. Tardif, E.; Doudin, P.A.; Meylan, N. Neuromyths Among Teachers and Student Teachers. Mind Brain Educ. 2015, 9, 50-59. [CrossRef]

60. Fuentes, A.; Risso, A. Evaluación de conocimientos y actitudes sobre neuromitos en furturos/as maestros/as. R. Est. Inv. Psico. Y Educ. 2015, 6, 193-198. [CrossRef]

61. Rigoulot, S.; Pell, M.D. Seeing emotion with your ears: Emotional prosody implicitly guides visual attention to faces. PLoS ONE 2012, 7, 30740. [CrossRef]

62. Thompson, L.; White, B. Neuropsychological correlates of evocative multimodal 988 speech: The combined roles of fearful prosody, visuospatial attention, cortisol response, and anxiety. Behav. Brain Res. 2022, 416, 113560. [CrossRef]

63. Rato, J.; Abreu, A.; Castro-Caldas, A. Neuromyths in Education: What is fact and what is fiction for Portuguese teachers. Educ. Res. 2013, 55, 441-453. [CrossRef]

64. Gettliffe, N. Les recherches portant sur L'Approche neurolinguistique pour l'enseignement des langues étrangères et secondes: Axes actuels et perspectives. Le Cah. De L'arefle 2020, 1, 136-174.

65. Gardner, H. Multiple Intelligences: The Theory in Practice; Basic Book: New York, NY, USA, 1993.

66. Xu, M.; Li, D.; Li, P. Brain decoding in multiple languages: Can cross-language brain decoding work? Brain Lang. 2021, 215, 104922. [CrossRef] [PubMed]

67. Umejima, K.; Sakai, K.L. Multilingualism and the Development of the Brain. Brain Nerve=Shinkei Kenkyu No Shinpo 2021, 73, 203-210. [CrossRef] [PubMed] 